\title{
Evaluation of heavy metals and metabolites in the urine of patients with breast cancer
}

\author{
YUHAO MEN $^{1,2}$, LING LI $^{1}$, FEN ZHANG $^{1}$, XUEYUAN KONG ${ }^{1}$, \\ WEIDONG ZHANG ${ }^{2}$, CHONGLI HAO $^{1}$ and GUOTIAN WANG ${ }^{1}$ \\ ${ }^{1}$ Department of Oncology, Affiliated Tengzhou Central People's Hospital of Jining Medical University, \\ Tengzhou, Shandong 277599; ${ }^{2}$ Department of Animal Breeding, College of Animal Sciences \\ and Technology, Qingdao Agricultural University, Qingdao, Shandong 266109, P.R. China
}

Received January 8, 2019; Accepted September 20, 2019

DOI: $10.3892 / 01.2019 .11206$

\begin{abstract}
Epidemiologic studies demonstrated that the environment serves a crucial role in cancer development. Heavy metals, including arsenic (As), cadmium (cd), chromium $(\mathrm{Cr})$, lead and mercury, are considered to be carcinogens or co-carcinogens. Furthermore, $\mathrm{Cd}$ has been detected in breast cancer (BC) tissue at high concentrations. The present study aimed to investigate the correlation between heavy metals detected in urine and urine metabolome of patients with BC, and their association with cancer development. Nuclear magnetic resonance was used to determine urine metabolites and an inductively coupled plasma mass spectrometry system was used to detect heavy metals in urine samples. The results demonstrated that $\mathrm{Cd}$ was markedly increased in the urine of patients with $\mathrm{BC}$ compared with the control population (approximately 2-fold). $\mathrm{Cr}$ and As were also increased in the urine of patients with BC. In addition, numerous small molecule metabolites were altered in the urine of patients with $\mathrm{BC}$ compared with the control population. This study also demonstrated that alterations in small molecule metabolites in the urine of patients with $\mathrm{BC}$ were very similar to results from a previous report. These findings indicated that environmental exposure to $\mathrm{Cd}$, $\mathrm{As}$, or $\mathrm{Cr}$ could influence the urine levels of metabolites, which may be involved in BC development. Further investigation is therefore required to examine a larger range of samples from different countries or areas in order to understand the impact of heavy metals on metabolism and BC development.
\end{abstract}

\section{Introduction}

Breast cancer (BC) is the most common in women, with a worldwide incidence of $\sim 13 \%$, in 2015 (1-3). Numerous studies demonstrated that the environment has crucial effects on the development of cancer and other diseases, such as infertility,

Correspondence to: Dr Ling Li, Department of Oncology, Affiliated Tengzhou Central People's Hospital of Jining Medical University, 181 Xingtan Road, Tengzhou, Shandong 277599, P.R. China

E-mail: lilingtz@163.com

Key words: breast cancer, urine, heavy metals, metabolome heart disease and lung cancer $(4,5)$. It has been reported that environmental contamination cause $20 \%$ of all diseases, and that $>30 \%$ of these diseases affect children (4). An environment less contaminated would therefore minimize the occurrence of numerous diseases/disorders and associated morbidity (5). Investigating the mechanisms of $\mathrm{BC}$ development and determining novel potential biomarkers for this disease are therefore crucial (6).

Metabolomics is one of the newest 'omics' sciences that has been recently developed to determine novel biomarkers for multiple human diseases/disorders, and that could be used to understand the underlying mechanisms of cancer development (7). It has been reported that metabolome changes can reflect the pathophysiological status of biological systems, such as in ovarian and liver cancer (8). In particular, the urine metabolome has recently attracted much attention (9-11), since urine is adapted to metabolic profiling and clinical biomarker screening $(12,13)$. Studying urinary metabolomics offers numerous advantages: i) Urine is a highly accessible specimen type; ii) the sample collection is non-invasive; iii) the matrix is simple; and iv) less or no sample preparation is needed before analysis (9). It was demonstrated that urinary metabolomics represents a transformative novel approach in the discovery of cancer biomarkers and has a high translational ability for early cancer screening (9).

Nuclear magnetic resonance (NMR) spectroscopy, in particular 1H NMR, which is the most popular NMR technique, has been used in metabolome studies since it can detect metabolomic changes in cells, tissues, biofluids or live animals in vivo $(7,14-17)$. NMR spectroscopy offers numerous advantages for metabolic studies, as it requires little or no sample preparation prior to analysis. The NMR method is fast, non-invasive, non-destructive and highly reproducible (18). NMR has therefore been extensively applied in metabolic studies (14-18).

Heavy metals negatively affect humans in many ways, since they exist in the entire environment (air, water, oil and sediments) (19-22). As they can enter the body through inhalation, ingestion and skin absorption, heavy metals are found in all human tissues. They can interfere with numerous metabolic processes, resulting in toxicity (19-22). It has been reported that urinary heavy metals can be considered 
as biomarkers for cancer development in liver, prostate and lung cancer (11,23-25). Cadmium $(\mathrm{Cd})$, lead $(\mathrm{Pb})$, mercury $(\mathrm{Hg})$ and tin $(\mathrm{Sn})$ were reported to be toxic because they can mimic or block the functions of other essential metals (26). Furthermore, $\mathrm{Cd}$, chromium $(\mathrm{Cr})$, nickel $(\mathrm{Ni})$, copper $(\mathrm{Cu})$, $\mathrm{Pb}$ and $\mathrm{Hg}$ have been demonstrated to be carcinogenic and induce lung, liver, larynx, esophageal, prostate, breast and gastrointestinal cancers (27-31). However, the correlation between urinary levels of heavy metals and metabolomes in patients with $\mathrm{BC}$, and their association with cancer development remain unknown. The present study aimed therefore to investigate the metabolome and heavy metals level in the urine of patients with $\mathrm{BC}$ at first diagnosis.

\section{Materials and methods}

Patient population and urine sample collection. Urine samples from patients with $\mathrm{BC}(\mathrm{n}=106)$ and age-matched healthy women $(n=38)$ were collected from the Affiliated Tengzhou Central People's Hospital of Jining Medical University of Jining Medical University between September 2017 and July 2018. Patients with BC and women of the control population were from the same local area (Tengzhou city, Shandong Province, China). The patients recruited into the study have never smoked. Since there are lots of mines in this area, the heavy metals contamination is relatively high. The study was performed according to the standards of the Institutional Ethics Committee and the Helsinki Declaration of 1975, as revised in 1983, and was approved by the Institutional Review Board of the Affiliated Tengzhou Central People's Hospital of Jining Medical University. All patients and healthy volunteers provided informed consent prior to the study. Patients with BC were selected according to the following criteria: i) Female sex; ii) patients diagnosed with $\mathrm{BC}$ following hematoxylin and eosin staining of biopsy sections; iii) patients with early stage BC (stages I-II) according to the Tumor-Node-Metastasis classification (32); iv) patients who received no preoperative treatment, including adjuvant chemotherapy or radiotherapy; and v) patients without diabetes or other simultaneous diseases. The healthy volunteers selected were age- and gender-matched, did not suffer from metabolic diseases, and were confirmed to have no breast lesions following physical examination, mammography and ultrasonography of the breast. Prior to surgery and following overnight fasting, 20 urine samples were collected from patients with $\mathrm{BC}$ over a 24 -h time period and samples were combined for each patient. A total of 10 urine samples were also collected over a 24-h time period from healthy volunteers that were fasting overnight. A $20 \mathrm{ml}$ urine sample was used for each patient or healthy subject and centrifuged at $1,500 \mathrm{xg}$ for $15 \mathrm{~min}$ at $4^{\circ} \mathrm{C}$ in order to collect the supernatant. Supernatants were transferred into sterile vials and immediately stored at $-80^{\circ} \mathrm{C}$ until further experiments.

NMR spectroscopy. NMR analysis was performed as previously described (33-40). Briefly, prior to NMR spectroscopy, $200 \mu \mathrm{l}$ urine supernatant was mixed with $80 \mu \mathrm{l}$ deuteroxide solution containing sodium phosphate buffer $(0.1 \mathrm{M} ; \mathrm{pH}$ 7.4) and sodium 3-trimethylsilyl-2,2,3,3-d4-propionate (all Sigma-Aldrich; Merck KGaA) as an internal standard ( $\delta=0$ $\mathrm{ppm})$, then sample was injected. The $1 \mathrm{H}$ NMR spectra were acquired using a $600.13 \mathrm{MHz}$ Bruker AV600 spectrometer (Bruker Corporation) with a 5-mm CryoProbe (Bruker Corporation) at $300 \mathrm{~K}$. Nuclear overhauser effect spectroscopy and a zg pulse (a $90^{\circ}$ excitation pulse) sequence of $1 \mathrm{H}$ NMR spectra, and zgpr pulse sequence of J-resolved NMR spectra were used to acquire NMR information. NMR data were acquired using a T2-relaxation-filtered pulse sequence, which suppressed most of the broad macromolecule and lipoprotein lipid signals and enhanced the detection of smaller molecules. Data were recorded with $64 \mathrm{k}$ data points using 24 (or 16) transients acquired after four steady-state scans with a Bruker 1D CPMG pulse sequence with water peak suppression and a $78 \mathrm{msec}$ T2-filter with a fixed echo delay of $403 \mathrm{msec}$ to minimize diffusion and J-modulation effects. The acquisition time was $3.3 \mathrm{sec}$ and the relaxation delay was $3.0 \mathrm{sec}$. Data were processed and phase corrected in an automated fashion. Prior to Fourier transformations to spectra, the measured free induction decays for windows were zero-filled to $128 \mathrm{k}$ data points and multiplied with an exponential window function with a $1.0 \mathrm{~Hz}$ line broadening.

NMR spectral processing and analysis. The 1H NMR spectra were processed using MestRe-C (version 3.0) software as previously described (33). Briefly, the spectra were binned with a unit of $0.005 \mathrm{ppm}$ between 0.2 and $10.0 \mathrm{ppm}$, and then integrated spectral intensity for each bin. The binned data were adjusted by generalized log transformation and mean-centered prior to multivariate analysis.

Multivariate analyses. The processed NMR datasets were examined using principal component analysis (PCA) and partial least squares discriminant analysis (PLS-DA) through the SIMCA-P10.0 software package (version 10; Umetrics $\mathrm{ABn}$ ) as previously described (33). Briefly, PCA was used to reduce the complexity of the metabolomics data matrix without additional information and provided the visual performance of the original cluster for each group. PLS-DA connected the classified information and NMR dataset to determine the variance between the different groups. Two-dimensional score plots were used to visualize the separation of the samples, and the corresponding loading plots were applied to identify the spectral variable contribution to the position of the spectra that were altered by different conditions.

Mineral element quantification. The determination of mineral elements was completed via inductively coupled plasma mass spectrometry (ICPMS) as previously described $(36,37)$. Briefly, $5 \mathrm{ml}$ aliquots of urine were freeze-dried, $5 \mathrm{ml} 98 \%$ nitric acid (Sanye Chemical Corporation) was added, then the mixture was transferred into $120 \mathrm{ml}$ Teflon digestion vessels. Samples underwent microwave digestion at $100^{\circ} \mathrm{C}$ for $30 \mathrm{~min}$. The concentrated nitric acid was used to destroy the organic content and mineralize the sample. The multi-element calibration standards were provided at the concentration of $10 \mathrm{mg} / \mathrm{l}$ in 5\% nitric acid. An Agilent 7500 ICPMS system (Agilent Technologies, Inc.) was used to simultaneously determination the levels of $\mathrm{Cd}, \mathrm{Cr}, \mathrm{As}, \mathrm{Pb}$ and $\mathrm{Hg}$. The voltage for the ion lens was set at $6 \mathrm{~V}$; the gas flow rate in the spray chamber was set at $0.88 \mathrm{l} / \mathrm{min}$; the power output for the RF generator was set at $1,100 \mathrm{~W}$; the auxiliary gas flow rate was set at 1.2 

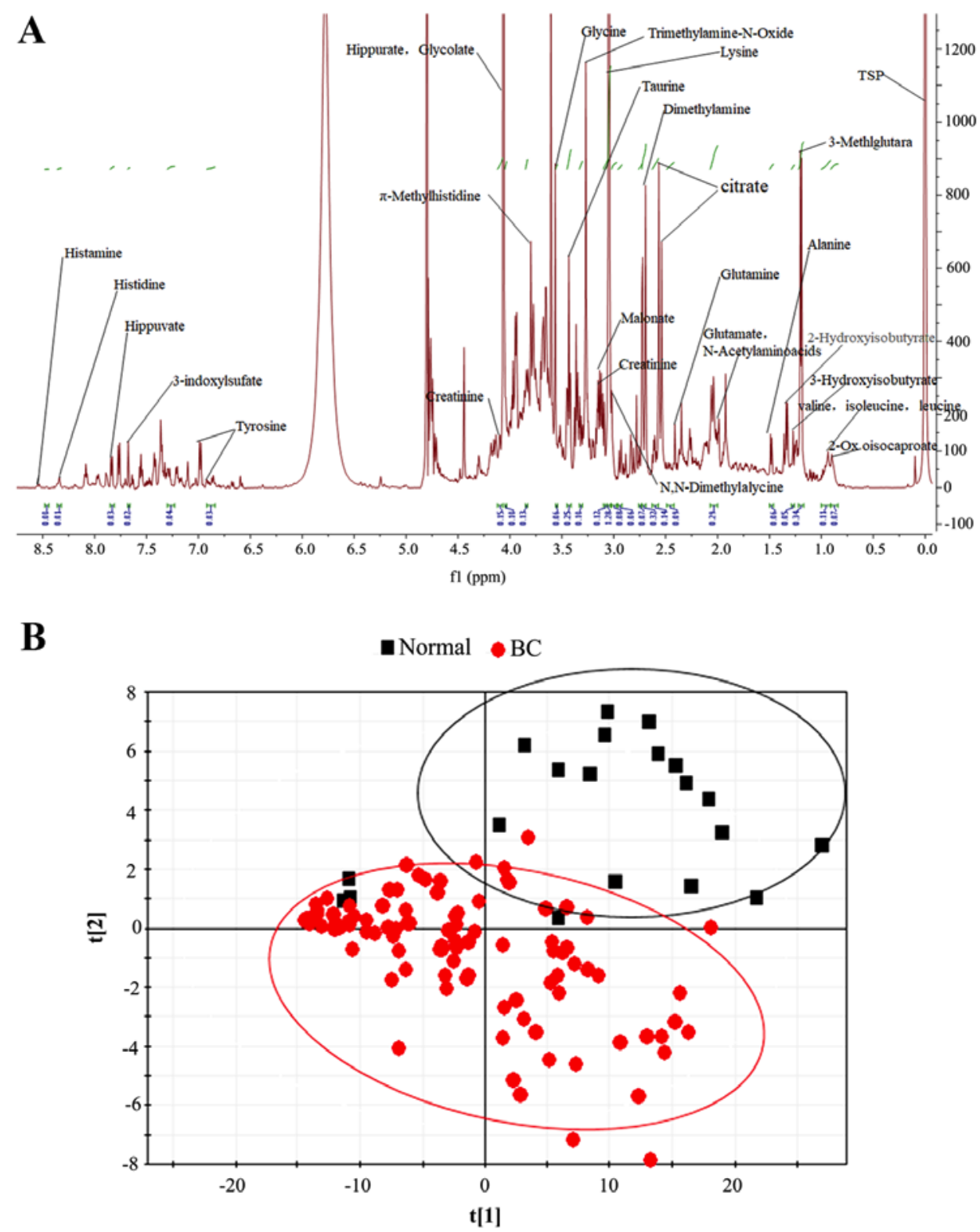

Figure 1. ${ }^{1} \mathrm{H}$ NMR analysis of small molecule metabolites from urine sample. (A) NMR spectral characteristics and metabolic contents of low molecular weight metabolites for patient with BC. (B) Score plot of the principal component analysis model from the analysis of ${ }^{1} \mathrm{H}$ NMR spectra of urine for low molecular weight metabolites from patients with $\mathrm{BC}$ and healthy volunteers. NMR, nuclear magnetic resonance; $\mathrm{BC}$, breast cancer.

$1 / \mathrm{min}$; and the nebulizer gas flow rate of the plasma was set at $16 \mathrm{l} / \mathrm{min}$. All certified reference materials (in solution) were purchased from the National Institute of Metrology. Blank (water) controls $(n=3)$ underwent the same procedures.

Statistical analyses. The data were statistically analyzed using SPSS statistics software (v21; IBM Corp.) and Student's t-test. Differences were compared for every parameter and data were expressed as the mean \pm SEM. $\mathrm{P}<0.05$ was considered to indicate a statistically significant difference.

\section{Results}

Baseline characteristics of the study population. The mean age of patients with BC (50.56 \pm 9.72 years) and of the control population (50.12 \pm 9.98 years) was similar (Table SI). Body mass index was also similar in the two groups (Table SI). At first diagnosis of BC (stages I or II), urine was collected over $24 \mathrm{~h}$ in order to determine the urine metabolome and levels of heavy metals.

Alteration in urine metabolome. The $1 \mathrm{H}$ NMR spectra from urine metabolites of a patient with BC presenting the small molecules metabolic fingerprints is shown in Fig. 1A. Chemical shift and peak multiplicity parameters were used to assign the specific urine metabolites as previously described (33,37-39). A total of 28 metabolites were detected in the urine samples of both patients with $\mathrm{BC}$ and controls, mostly amino acids and nucleotides.

Further biochemical information from the 1HNMR spectra was determined by partial least squares discriminant analysis. As seen in Fig. 1B, patients with BC and healthy volunteers presented two different metabolite populations according to score plots. These findings indicated that the metabolism of 

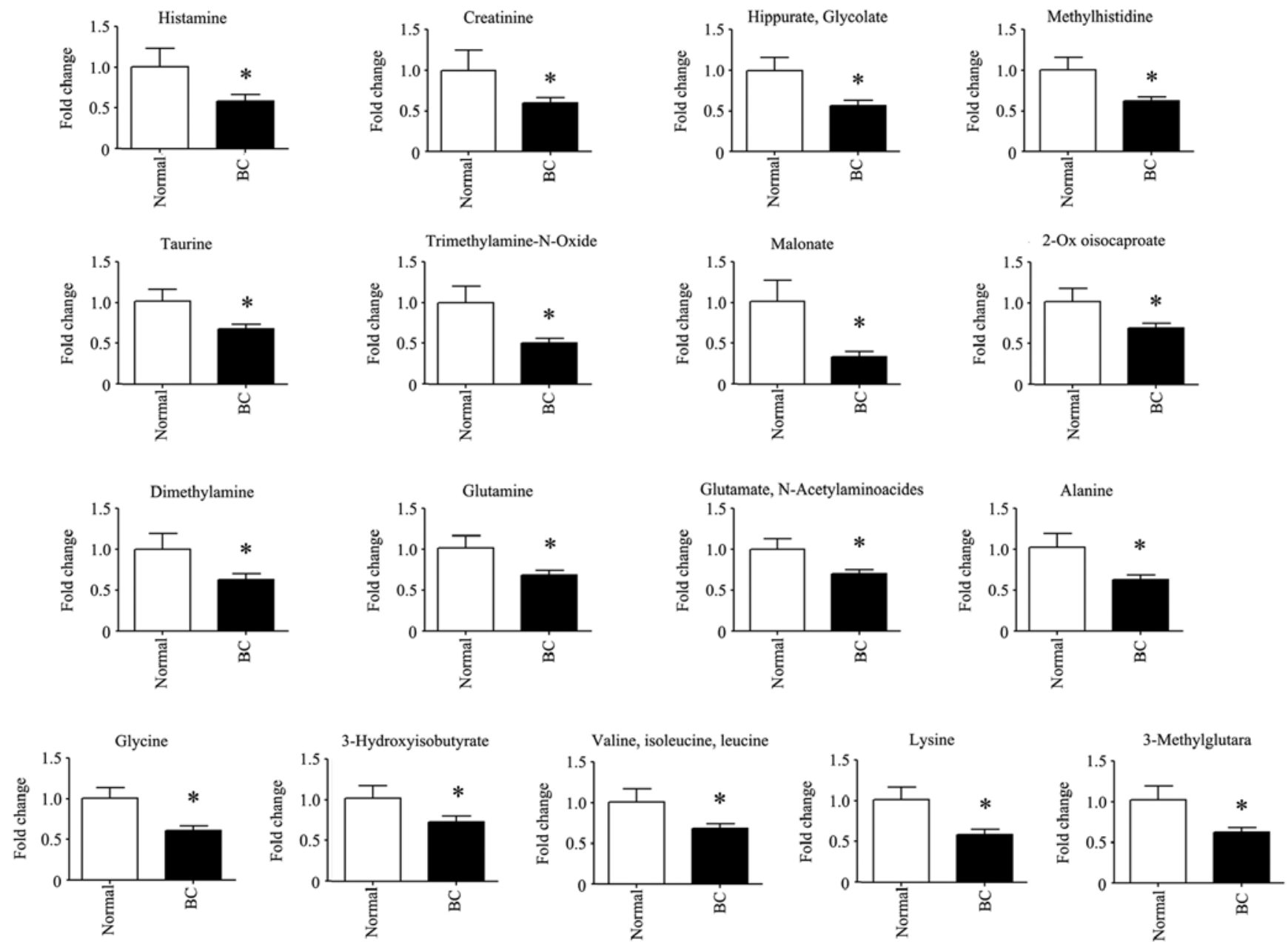

Figure 2. Small molecule metabolites were elevated in the urine of patients with BC compared with healthy volunteers. Data represent the means \pm SEM. ${ }^{*} \mathrm{P}<0.05$.

patients with BC may have been modified by the cancer itself or by other factors.

The amount of changed metabolites are presented in Fig. 2. The level of 17 urine metabolites [histamine, creatinine, hippurate (glycolate), methylhistidine, taurine, trimethylamine-N-oxide, malonate, 2-Ox oisocaproate, dimethylamine, glutamine, glutamate ( $\mathrm{N}$-acetylaminoacides) and alanine] was significantly decreased in patients with $\mathrm{BC}(\mathrm{P}<0.05)$ compared with the control population. Data were expressed as the fold change of patients with $\mathrm{BC}$ compared with the control population (control group was set as 1).

Content of urine heavy metals. The level of five common heavy metals $(\mathrm{Cd}, \mathrm{Cr}, \mathrm{As}, \mathrm{Pb}$ and $\mathrm{Hg})$ was determined in all urine samples. The relative concentration $(\mu \mathrm{g} / \mathrm{l})$ in urine samples from lowest to highest for the five metals was $\mathrm{Cd}, \mathrm{Hg}, \mathrm{As}, \mathrm{Pb}$, and $\mathrm{Cr}$. The concentration of As and $\mathrm{Hg}$ in all the samples was above zero. The three heavy metals $\mathrm{As}, \mathrm{Cd}$ and $\mathrm{Cr}$ were significantly higher in patients with $\mathrm{BC}$ compared with healthy volunteers (Fig. 3; $\mathrm{P}<0.05$ ), however, $\mathrm{Hg}$ and $\mathrm{Pb}$ were not significantly different. Furthermore, $\mathrm{Cd}$ was the most significantly increased metal in the urine of patients with $\mathrm{BC}$ compared with that in the control group (2.0-fold increase using mean value). These findings suggested that there may be a correlation between urine concentration in heavy metals and BC development. However, no association between urine level of heavy metals and $\mathrm{BC}$ histological type was described (data not shown).

\section{Discussion}

Apart from patient's genetic background, environmental factors serve a crucial role in BC development (41-49). BC is the most common type of disease in women worldwide. Environmental contamination by heavy metals has been reported to cause BC (41-49). As, Cd, and Ni have been classified as Group 1 human carcinogens by the World Health Organization (50). Furthermore, $\mathrm{Pb}, \mathrm{Hg}$, and $\mathrm{Cr}$ have been classified as human and animal carcinogens or co-carcinogens (27-30). The results from the present study demonstrated that $\mathrm{Cd}$ was significantly higher in the urine of patients with BC compared with the control population ( $\sim 2$-fold). In addition, As and $\mathrm{Cr}$ were significantly higher in the urine of patients with $\mathrm{BC}$ compared with healthy volunteers. These findings indicated that $\mathrm{Cd}$, As and $\mathrm{Cr}$ may be involved in the development of BC. Numerous mines are located in the area where the patients and volunteers from the present study live, which leads to high local environmental contamination with heavy metals. This may also affect the levels of heavy metals in the urine. 

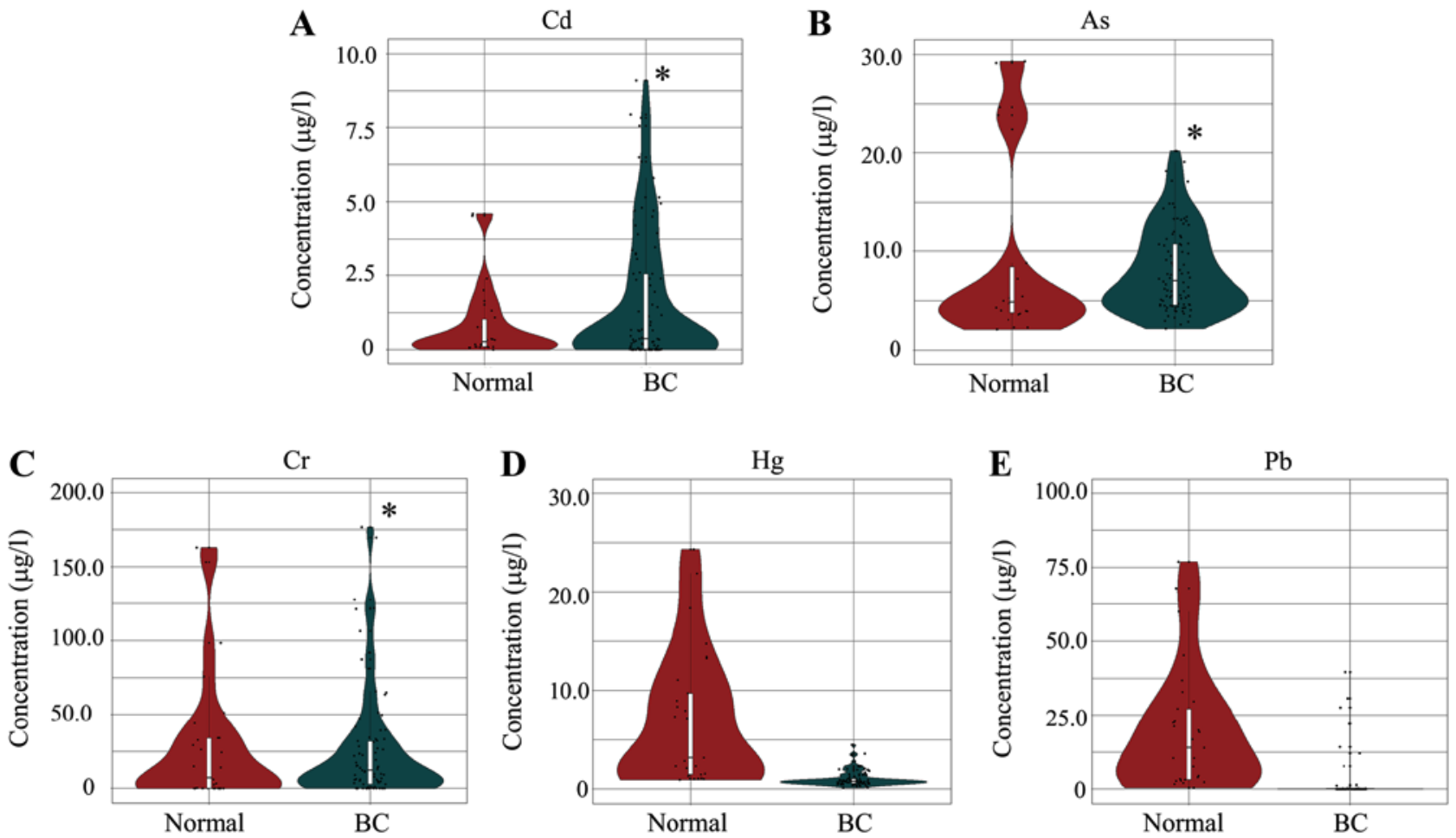

Figure 3. Concentration of five heavy metals in the urine of patients with $\mathrm{BC}$ and from the control population. Concentration of (A) Cd, (B) $\mathrm{As}$. (C) $\mathrm{Cr}$. (D) $\mathrm{Hg}$. (E) $\mathrm{Pb}$. The red color represents the normal control samples and the green color represents the $\mathrm{BC}$ samples for each metal. The density plot width represents the frequency. The white box represents the interquartile range. " $\mathrm{P}<0.05$. As, arsenic; $\mathrm{Cd}$, cadmium; $\mathrm{Cr}$, chromium; $\mathrm{Hg}$, mercury, $\mathrm{Pb}$, lead; $\mathrm{BC}$, breast cancer.

Heavy metals have been reported to cause numerous physiological disorders, including immunodeficiency, osteoporosis, neurodegeneration, organ failure and cancer (51). Environment contamination is the major source of heavy metal exposure in the general population (51). Cigarette smoking, dietary intake and water consumption are the main sources of $\mathrm{Cd}$ exposure in a population (52-54). Furthermore, a previous epidemiological study demonstrated that $\mathrm{Cd}$ exposure is correlated with $\mathrm{BC}$ development (51). In addition, $\mathrm{Cr}$ exposure has been reported to be a high risk factor for $\mathrm{BC}$, lung cancer, cancers of the buccal cavity, pharynx cancer, esophageal cancer, and non-Hodgkin lymphoma (55-58). As is also involved in the development of numerous cancers, including breast, skin, lung, bladder, liver and kidney, since As exposure can be mediated by food and water, and by inhalation of sawdust or smoke from burning As-treated materials (58-60). It has also been reported that other environmental contaminants, including polycyclic aromatic hydrocarbons, are highly detrimental to human health (61).

The present study demonstrated that patients with $\mathrm{BC}$ presented alterations in the small molecule metabolites compared with the control population, which was similar to results from Cala et al (10). Both these studies reported an overall decrease in intermediates of the tricarboxylic acid cycle and in amino acids and nucleotides in patients with $\mathrm{BC}$ compared with healthy subjects. Furthermore, Burton and Ma (9) analyzed the literature investigating the use of urinary metabolomics to develop cancer biomarkers, and reported a significant number of altered metabolic pathways and putative biomarkers, including pteridines, modified nucleosides, and acylcarnitines, which are all involved in cancer development and progression. The results from the present study were similar to the previous study by Cala et al (10) analyzing the urine metabolite composition in patients with $\mathrm{BC}$.

To the best of our knowledge, the association between urine level of heavy metals and metabolites in patients with $\mathrm{BC}$ has not been investigated. It is hypothesized that the urine level of $\mathrm{Cd}, \mathrm{Cr}$ and As may interact with urine metabolites in patients with BC.

The present study is preliminary, and the results demonstrated that urine level of heavy metals may affect the metabolism of patients $\mathrm{BC}$, which is hypothesized to influence $\mathrm{BC}$ development. However, the present study presented some limitations. The groups of patients and volunteers were small, and the numbers of samples were also different in these two groups. Furthermore, menopause status and hormonal replacement therapy was not included in the analysis and would be considered in future studies The results from the present study should be carefully interpreted since heavy metals represent only one cause of $\mathrm{BC}$ development. Other factors, such as environmental endocrine disrupting chemicals, air pollution, or particle materials (nanoparticles) may also affect breast cancer development. Further investigation should therefore include a higher number of samples from different countries or areas in order to understand the impact of heavy metals on patients metabolism and $\mathrm{BC}$ occurrence. Future study will investigate the impact of heavy metal exposure on $\mathrm{BC}$ progression and on the prognosis of patients with $\mathrm{BC}$. Urinary metabolomics have been found to have many advantages and it was demonstrated that urinary metabolomics represents a novel approach in the discovery of cancer biomarkers and has a high translational ability for early cancer screening (9). 


\section{Acknowledgements}

Not applicable.

\section{Funding}

The present study was funded by the Shandong Province Medical and Health Technology Development Project (grant no. 2016WS0627; Ethic no. 2017-Ethic review-03) and the Supporting Fund for Teachers' Research of Jining Medical University (grant no. JY2016KJ041Y; Ethic No. 2017-Ethic review-04).

\section{Availability of data and materials}

The datasets used and/or generated during the current study are available from the corresponding author on reasonable request.

\section{Author's contributions}

LL and YM provided key intellectual input in the conception and design of these studies and YM wrote the manuscript. FZ, $\mathrm{XK}, \mathrm{WZ}, \mathrm{CH}$, and GW collected the samples and performed analyses. WZ contributed to the writing of the manuscript. All authors reviewed the final manuscript.

\section{Ethics approval and consent to participate}

All procedures performed in studies involving human participants were in accordance with the ethical standards of the institutional and/or national research committee and with the 1964 Helsinki declaration and its later amendments or comparable ethical standards. Informed consent was obtained from all individual participants included in the study.

\section{Patient consent for publication}

Not applicable

\section{Competing interests}

The authors declare that they have no competing interests.

\section{References}

1. Ferlay J, Soerjomataram I, Ervik M, Dikshit R, Eser S, Mathers C Rebelo M, Parkin DM, Forman D and Bray F: GLOBOCAN 2012 v1.0, cancer incidence and mortality worldwide: IARC cancer base no. 11 [Internet]. International Agency for Research on Cancer, Lyon, 2014.

2. Ledda C, Iavicoli I, Bracci M, Avola R, Senia P, Santarelli L, Pomara C and Rapisarda V: Serum lipid, lipoprotein and apolipoprotein profiles in workers exposed to low arsenic levels: Lipid profiles and occupational arsenic exposure. Toxicol Lett 282: 49-56, 2018.

3. Siegel R, Naishadham D and Jemal A: Cancer statistics, 2012. CA Cancer J. Clin 62: 10-29, 2012.

4. Prüss-Üstün A and Corvalán C: Preventing disease through healthy environments. Towards an estimate of the environmental burden of disease. World Health Organization, France, 2006.

5. Rzymski P, Tomczyk K, Rzymski P, Poniedziałek B, Opala T and Wilczak M: Impact of heavy metals on the female reproductive system. Ann Agric Environ Med 22: 259-264, 2015.
6. Howell A, Anderson AS, Clarke RB, Duffy SW, Evans DG, Garcia-Closas M, Gescher AJ, Key TJ, Saxton JM and Harvie MN: Risk determination and prevention of breast cancer. Breast Cancer Res 16: 446, 2014

7. Kruk J, Doskocz M, Jodłowska E, Zacharzewska A, Łakomiec J, Czaja $\mathrm{K}$ and Kujawski J: NMR techniques in metabolomic studies: A quick overview on examples of utilization. Appl Magn Reson 48: 1-21, 2017.

8. Denkert C, Budczies J, Kind T, Weichert W, Tablack P, Sehouli J, Niesporek S, Könsgen D, Dietel M and Fiehn O: Mass spectrometry-based metabolic profiling reveals different metabolite patterns in invasive ovarian carcinomas and ovarian borderline tumors. Cancer Res 66: 10795-10804, 2006.

9. Burton $\mathrm{C}$ and Ma Y: Current trends in cancer biomarker discovery using urinary metabolomics: Achievements and new challenges. Curr Med Chem 26: 5-28, 2019.

10. Cala M, Aldana J, Sánchez J, Guio J and Meesters RJW: Urinary metabolite and lipid alterations in Colombian Hispanic women with breast cancer: A pilot study. J Pharm Biomed Anal 152: 234-241, 2018.

11. Eriksen KT, McElroy JA, Harrington JM, Levine KE, Pedersen C, Sørensen M, Tjønneland A, Meliker JR and Raaschou-Nielsen O: Urinary cadmium and breast cancer: A prospective danish cohort study. J Natl Cancer Inst 109: pii: djw204, 2016.

12. Zhang T, Watson DG, Wang L, Abbas M, Murdoch L, Bashford L, Ahmad I, Lam NY, Ng AC and Leung HY: Application of holistic liquid chromatography-high resolution mass spectrometry based urinary metabolomics or prostate cancer detection and biomarker discovery. PLoS One 8: e65880, 2013.

13. Zhang A, Sun H, Wang P, Han Y and Wang X: Modern analytical techniques in metabolomics analysis. Analyst 137: 293-300, 2012.

14. Suhre K, Shin SY, Petersen AK, Mohney RP, Meredith D, Wägele B, Altmaier E, CARDIoGRAM, Deloukas P, Erdmann $\mathrm{J}$, et al: Human metabolic individuality in biomedical and pharmaceutical research. Nature 477: 54-60, 2011.

15. Bictash M, Ebbels TM, Chan Q, Loo RL, Yap IK, Brown IJ, de Iorio M, Daviglus ML, Holmes E, Stamler J, et al: Opening up the 'Black Box': Metabolic phenotyping and metabolome-wide association studies in epidemiology. J Clin Epidemiol 63: 970-979, 2010.

16. Claudino WM, Quattronem A, Biganzoli L, Pestrin M, Bertini I and Di Leo A: Metabolomics: Available results, current research projects in breast cancer, and future applications. J Clin Oncol 25: 2840-2846, 2007.

17. Holmes E, Loo RL, Stamler J, Bictash M, Yap IK, Chan Q, Ebbels T, De Iorio M, Brown IJ, Veselkov KA, et al: Human metabolic phenotype diversity and its association with diet and blood pressure. Nature 453: 396-400, 2008.

18. Norvig P, Relman DA and Goldstein DB: 2020 visions. Nature 463: 26-32, 2010.

19. Jaishankar M, Tseten T, Anbalagan N, Mathew BB and Beeregowda KN: Toxicity, mechanism and health effects of some heavy metals. Interdiscip Toxicol 7: 60-72, 2014.

20. Vimercati L, Gatti MF, Gagliardi T, Cuccaro F, De Maria L, Caputi A, Quarato M and Baldassarre A: Environmental exposure to arsenic and chromium in an industrial area. Environ Sci Pollut Res Int 24: 11528-11535, 2017.

21. Vimercati L, Baldassarre A, Gatti MF, Gagliardi T, Serinelli M, De Maria L, Caputi A, Dirodi AA, Galise I, Cuccaro F and Assennato G: Non-occupational exposure to heavy metals of the residents of an industrial area and biomonitoring. Environ Monit Assess 188: 673, 2016.

22. IARC monographs on the evaluation of carcinogenic risks to humans: Chromium, nickel, and welding. Chromium and chromium compounds, IARC, Lyon, 1990.

23. Larsson SC, Orsini $\mathrm{N}$ and Wolk A: Urinary cadmium concentration and risk of breast cancer: A systematic review and dose-response meta-analysis. Am J Epidemiol 182: 375-380, 2015.

24. Wei XL, He JR, Cen YL, Su Y, Chen LJ, Lin Y, Wu BH, Su FX, Tang LY and Ren ZF: Modified effect of urinary cadmium on breast cancer risk by selenium. Clin Chim Acta 438: 80-85, 2015.

25. Qin YC, Tang LY, Su Y, Chen LJ, Su FX, Lin Y, Zhang AH and Ren ZF: Association of urinary cesium with breast cancer risk. Asian Pac J Cancer Prev 15: 9785-9790, 2014.

26. Waalkes MP, Fox DA, States JC, Patierno SR and McCabe MJ: Metals and disorders of cell accumulation: Modulation of apoptosis and cell proliferation. Toxicol Sci 56: 255-261, 2000. 
27. Hayes RB: The carcinogenicity of metals in humans. Cancer Causes Control 8: 371-385, 1997.

28. IARC monographs on the evaluation of the carcinogenic risk of chemicals to humans: Some metals and metallic compounds. Lyon, France, 1980.

29. Gilman JPW and Smierenga SHH: Inorganic carcinogenesis. In: Searle CE (ed). Chemical carcinogens, ACS monograph no. 182 2 edition. Vol. 1. American Chemical Society; Washington, DC, pp577, 1980 .

30. Norseth T: The carcinogenicity of chromium. Environ Health Persp 40: 121-130, 1981

31. Barlow SM and Sullivan FM: Reproductive hazards and industrial chemicals. Ann Occup Hyg 24: 359-361, 1981.

32. Veronesi U, Zurrida S, Viale G, Galimberti V, Arnone P and Nolè F: Rethinking TNM: A breast cancer classification to guide to treatment and facilitate research. Breast J 15: 291-295, 2009.

33. Zhang W, Zhao Y, Li F, Li L, Feng Y, Min L, Ma D, Yu S, Liu J, Zhang H, et al: Zinc oxide nanoparticle caused plasma metabolomic perturbations correlate with hepatic steatosis. Front Pharmacol 9: 57, 2018.

34. Soininen $\mathrm{P}$, Kangas AJ, Würtz $\mathrm{P}$, Tukiainen T, Tynkkynen T, Laatikainen R, Järvelin MR, Kähönen M, Lehtimäki $T$, Viikari J, et al: High-throughput serum NMR metabonomics for cost-effective holistic studies on systemic metabolism. Analyst 134: 1781-1785, 2009.

35. Lee SH, Wang TY, Hong JH, Cheng TJ and Lin CY: NMR-based metabolomics to determine acute inhalation effects of nano- and fine-sized $\mathrm{ZnO}$ particles in rat lung. Nanotoxicology 10: 924-934, 2016.

36. Zhao Y, Feng YN, Li L, Zhang HF, Zhang YN, Zhang PF, Liu XQ, Zhang WD, Huang TT, Zhao L, et al: Tissue-specific regulation of the contents and correlations of mineral elements in hens by zinc oxide nanoparticles. Biol Trace Elem Res 177: 353-366, 2017.

37. Zimeri AM, Robb SW, Hassan SM, Hire RR and Davis MB: Assessing heavy metal and PCB exposure from tap water by measuring levels in plasma from sporadic breast cancer patients, a pilot study. Int J Environ Res Public Health 12: 15683-15691, 2015.

38. Mäkinen VP, Soininen P, Forsblom C, Parkkonen M, Ingman P, Kaski K and Groop PH; FinnDiane Study Group and Ala-Korpela M: 1H NMR metabonomics approach to the disease continuum of diabetic complications and premature death. Mol Syst Biol 4: 167, 2008.

39. Yan G, Huang Y, Bu Q, Lv L, Deng P, Zhou J, Wang Y, Yang Y, Liu Q, Cen X and Zhao Y: Zinc oxide nanoparticles cause nephrotoxicity and kidney metabolism alterations in rats. J Environ Sci Health A Tox Hazard Subst Environ Eng 47: 577-588, 2012.

40. Wan Q, He Q, Deng X, Hao F, Tang H and Wang Y: Systemic metabolic responses of broiler chickens and piglets to acute T-2 toxin intravenous exposure. J Agric Food Chem 64: 714-723, 2016.

41. Wood RY and Della-Monica NR: Psychosocial factors influencing breast cancer risk appraisal among older women. Qual Health Res 21: 783-795, 2011.

42. Salhab M, Bismohun S and Mokbel K: Risk-reducing strategies for women carrying BRCA1/2 mutations with a focus on prophylactic surgery. BMC Womens Health 10: 28, 2010.

43. Jevtic M, Velicki R, Popovic M, Cemerlic-Adjic N, Babovic S and Velicki L: Dietary influence on breast cancer. J BUON 15 : 455-461, 2010

44. Ebrahim AM, Eltayeb M, Shaat M, Mohmed NM, Eltayeb E and Ahmed AY: Study of selected trace elements in cancerous and non-cancerous human breast tissues from Sudanese subjects using instrumental neutron activation analysis. Sci Total Environ 383: 52-58, 2007

45. Florea AM and Büsselberg D: Metals and breast cancer: Risk factors or healing agents? J Toxicol 2011: 159619, 2011.
46. Ilychova SA and Zaridze DG: Cancer mortality among female and male workers occupationally exposed to inorganic lead in the printing industry. Occup Environ Med 69: 87-92, 2012.

47. Qu W, Tokar EJ, Kim AJ, Bell MW and Waalkes MP: Chronic cadmium exposure in vitro causes acquisition of multiple tumor cell characteristics in human pancreatic epithelial cells. Environ Health Perspect 120: 1265-1271, 2012.

48. Cheung MR: Blood lead concentration correlates with all cause, all cancer and lung cancer mortality in adults: A population based study. Asian Pac J Cancer Prev 14: 3105-3108, 2013.

49. Person RJ, Tokar EJ, Xu Y, Orihuela R, Ngalame NN and Waalkes MP: Chronic cadmium exposure in vitro induces cancer cell characteristics in human lung cells. Toxicol Appl Pharmacol 273: 281-288, 2013.

50. Wadhwa SK, Kazi TG, Afridi HI, Talpur FN and Naeemullah: Interaction between carcinogenic and anti-carcinogenic trace elements in the scalp hair samples of different types of Pakistani female cancer patients. Clin Chim Acta 439: 178-184, 2015.

51. Byrne C, Divekar SD, Storchan GB, Parodi DA and Martin MB: Metals and breast cancer. J Mammary Gland Biol Neoplasia 18: 63-73, 2013.

52. Gartell MJ, Craun JC, Podrebarae DS and Gunderson ER: Pesticides, selected elements, and other chemicals in adult total diet samples, October 1980-March 1982. J Assoc Off Anal Chem 69: 146-159, 1986.

53. Gartell MJ, Craun JC, Podrebarae DS and Gunderson ER: Pesticides, selected elements, and other chemicals in infant and toddler total diet samples, October 1980-March 1982. J Assoc Off Anal Chem 69: 123-145, 1986.

54. Lucas JM: Burea of mines. US Department of the Interior. Cadmium. Bulletin, pp671, 1980.

55. Núñez O, Fernández-Navarro P, Martín-Méndez I, Bel-Lan A, Locutura JF and López-Abente G: Arsenic and chromium topsoil levels and cancer mortality in Spain. Environ Sci Pollut Res Int 23: 17664-17675, 2016.

56. Peralta-Videa JR, Lopez ML, Narayan M, Saupe G and Gardea-Torresdey J: The biochemistry of environmental heavy metal uptake by plants: Implications for the food chain. Int J Biochem Cell Biol 41: 1665-1677, 2009.

57. Welling R, Beaumont JJ, Petersen SJ, Alexeeff GV and Steinmaus C: Chromium VI and stomach cancer: A meta-analysis of the current epidemiological evidence. Occup Environ Med 72: 151-159, 2015.

58. ATSDR: Toxicological profile for arsenic. Agency for toxic substances and disease registry (ATSDR). U.S. Department of Health and Human Services, Atlanta, 2007.

59. IARC Arsenic, metals, fibres and dusts. IARC monographs on the evaluation of carcinogenic risks to humans, vol $100 \mathrm{c}$. International Agency for Research on Cancer, Lyon, 2012.

60. Muszyńska M, Jaworska-Bieniek K, Durda K, Sukiennicki G Gromowski T, Jakubowska A, Morawski A and Lubiński J: Arsenic (As) and breast cancer risk. Hered Cancer Clin Pract 10, 2012.

61. Campo L, Vimercati L, Carrus A, Bisceglia L, Pesatori AC, Bertazzi PA, Assennato G and Fustinoni S: Environmental and biological monitoring of PAHs exposure in coke-oven workers at the Taranto plant compared to two groups from the general population of Apulia, Italy. Med Lav 103: 347-360, 2012.

This work is licensed under a Creative Commons Attribution-NonCommercial-NoDerivatives 4.0 International (CC BY-NC-ND 4.0) License. 